\title{
Franchised fast food brands: An empirical study of factors influencing growth
}

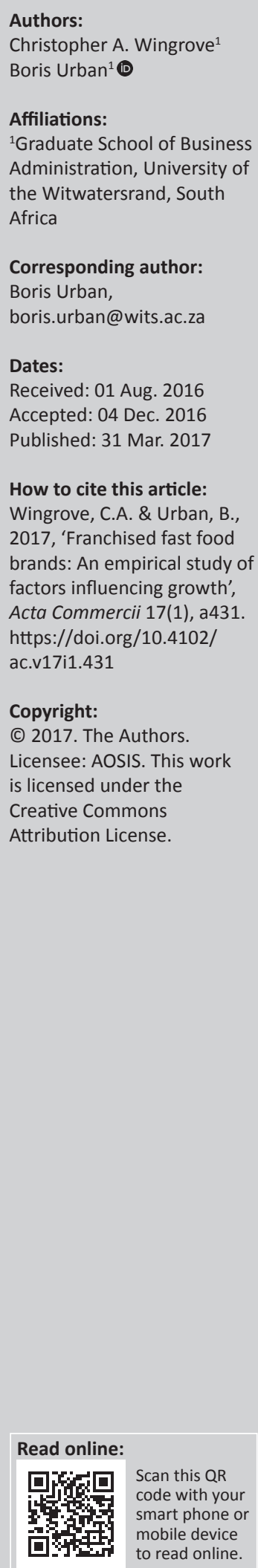

Orientation: Franchising is a popular and multifaceted business arrangement that captures a sizeable portion of the restaurant industry worldwide.

Research purpose: The study empirically investigated the influence of various site location and branding factors on the growth of franchised fast food restaurant brands across the greater Gauteng region.

Motivation of the study: Researching which factors influence the growth of franchised fast food restaurant brands is important for an emerging market context such as South Africa when considering the marked increase in the consumption of fast foods.

Design: A sample of 140 customers was surveyed from 12 leading franchised fast food outlets. Primary data were collected for various items representing site location and brand factors. Regression analysis was used to test the hypotheses.

Findings: The overall findings showed that convenience and central facilities of a retail location are positively and significantly associated with the growth of the franchise fast food outlet.

Practical implications: The study findings have implications for practitioners who need to take into account which factors influence revenue growth, since targeted interventions may be required to implement sustainable strategies by franchisors.

Contribution: The findings may serve as a catalyst for this growing and important activity in South Africa and other emerging markets.

\section{Introduction}

Franchising is a popular and multifaceted business arrangement that has attracted considerable research attention (Combs, Michael \& Castrogiovanni 2004; Michael \& Combs 2008:74). Franchising is prevalent across multiple sectors, including retail, service and manufacturing, and represents a high percentage of sales in various countries and regions, such as in the UK, US, Australia, Italy and the Pacific Rim and Middle East regions (International Franchise Association 2015:2-3). Additionally, franchising is one of the key forms of global expansion and entrance into foreign markets for international businesses, with millions of franchisees worldwide (Hsu, Jang \& Canter 2010:441; Shaw 2009:33).

Despite the importance of franchising to the South African economy and the restaurant industry, little research has been conducted at a store level across franchised fast food restaurant brands. This is a serious oversight as franchising captures a sizeable portion of the restaurant industry worldwide and plays an important role in its growth (Hsu et al. 2010). Moreover, researching franchised fast food restaurant brands is important for an emerging market context such as South Africa, when considering the marked increase in the consumption of affordable, large-portioned and immediate fast foods (Terblanche \& Boshoff 2010:2; Van Zyl, Steyn \& Marais 2010:125).

The study stems from a problem of increased competition from both local and international franchise brands entering the South African market, forcing fast food restaurants to take cognisance of which factors influence their growth (Strydom 2014; Van Zyl et al. 2010).

Past studies on franchising as a topic of academic inquiry have tended to focus on the relationship between the franchisor and franchisee by investigating how the size, age, level of competition and number of franchised outlets influence the size of the total network distribution (Combs et al. 2004; Van Wyk \& De Jager 2009). However, more recently, various factors, including consumer 
perceptions, have been hypothesised to influence the performance and profitability of franchising (Kacker et al. 2013:22; Nijmeijer, Fabbricotti \& Huijsman 2013:62). For instance, research findings show that franchising relies substantially on location and convenience in order to attract consumers to their brands, with consumers being attracted to the store location as a result of the mix of the central facilities available within the retail location (North \& Kotze 2004:30). Fast food restaurants need to adjust to new market pressures to ensure that a wider net is cast across its consumer base in order to capture the full range of consumers as measured through the Living Standards Measure (LSM) 1 to 10 (Van Zyl et al. 2010).

Taking cognisance of the various factors influencing franchise performance and noting that research emphasis needs to shift towards understanding how franchising impacts organisational performance and drives growth (Combs et al. 2004:910; Hua \& Templeton 2010:57; Steyn, Labadarios \& Nel 2011:105), this study fills the literature gap by empirically investigating the influence of various factors on the growth of franchised fast food restaurant brands.

The article starts with a brief literature review. Hypotheses are then developed on the basis of past research and tested using regression analysis. Results and discussion follow, implications are highlighted and study limitations are addressed with future research recommended.

\section{Literature overview}

\section{Franchising in South Africa}

The franchising industry plays an important role in the South African economy and contributed over R302 billion revenue to the overall gross domestic product (GDP) in 2013 (Franchising Association South Africa [FASA] 2014:14-17). Within this industry, the fast food franchising sector leads by commanding approximately $22 \%$ of the overall franchise sector (Stats SA 2014:140-198). South Africa experienced a $160 \%$ increase (R516.3 million to R1342.9 million) in the income generated by the fast food industry between 2006 and 2012 (Stats SA 2014:140-190). The growth of the South African fast food industry has been attributed to factors such as rising household incomes, growth in the black middle class segment, participation of women in the labour force and the increasing value of household time (Mackay et al. 2013:68; Roberts-Lombard 2009:236).

Governmental, political, social and economic change in South Africa between 2001 and 2011 has shown a drastic shift in the consumer profile; the biggest shift has been the decline of $48 \%$ of the lower consumer profile as segmented by the LSM 1 to 4 . A major shift in the LSM 5 to 7 has been identified by a $57 \%$ increase in this segment, as well as a $45 \%$ increase in LSM 8 to 10 (South African Audience Research Foundation [SAARF] 2012). Therefore, the aggregated projected food sales in South Africa, for the period 2011 to 2016, are forecasted to grow at around 3.75\% (FASA 2014; SAARF 2012). This growing middle market leaves the fast food market open to both local and international players, where the key to success is primarily based on positioning in the market through site location and brand performance (North \& Kotze 2004:30).

\section{Franchising: Underlying theory}

Extant theory assumes that both franchisors and franchisees choose franchising in order to improve performance over time (Hua \& Dalbor 2013:724) and consequently revenue growth performance is operationalised as the study dependent variable. Traditionally, research on franchising has focused on agency costs (Michael \& Combs 2008:76) to ensure that the responsibility lies with the franchisor to maintain high quality franchisees across their network distribution. In this regard, business format franchising is a widespread form of operation (Nijmeijer et al. 2013); under this arrangement, advertising, brand building, productservice mix and overall quality monitoring of the franchised outlets remain the obligation of the franchisor to ensure that revenue growth and sustainability of both parties is maintained. While acknowledging the importance of such an arrangement and its derived benefits, several studies have further identified various factors that influence the performance and profitability of both the franchisor and franchisee (Kacker et al. 2013:25). Factors such as the franchise site location, convenience, quality of the physical environment and service of the restaurant, including its image and perceived customer value, have all been associated with improved performance (So et al. 2013:33).

Moreover, successful franchisors and retailers are customer centric and their strategic and tactical decisions revolve around their present and potential customers (Urban \& Kongo 2015:2). Store choice decisions in the food retailing industry have been widely discussed in the literature. A consumers' decision to shop at a store is in general based on location or convenience, assortment and quality of merchandise, service quality, price image, ambience conditions and promotions as well as brand selection (Jaravaza \& Chitando 2013:303).

Building on in this research direction several key variables are operationalised for the purpose of this study which have been identified in the literature as important factors to franchise growth. The selection of variables is by no means exhaustive. It is acknowledged that the actual process of franchisee sales growth is far more complex and that no single factor can determine the outcome of this process. Notwithstanding the complexity of the phenomenon and the reciprocal nature of relationships between different factors and franchise growth, hypotheses are formulated and restricted to a number of variables and links. These variables, which inform the hypotheses, are discussed below.

\section{Franchise site location factors}

Various models of site selection and location exist within the fast food and general retail environment, with the most 
prominent model, the location-allocation model (Goodchild 1984:87), analysing the relationship between the facilities available within the location as well as the demand density within the area (Frasquet, Gil \& Molla 2001:25). Additionally, the Shopping Centre Attractiveness (SCATTR) scale is based on 21 attributes and has been used successfully to assess which factors influence the attractiveness of shopping centres from a customer perspective (Wong, Lu \& Yuan 2001:26). The SCATTR scale includes factors such as family shopping environment, banking facilities, retail merchandising, food court, entertainment and parking availability. Additional attributes within the South African environment have been noted such as the need for security (North \& Kotze 2004:33). Building on previous research findings, a number of these site location factors are discussed below to inform our hypotheses.

Accessibility: Accessibility is the ease with which a customer can get into and out of a site. To assess a site's accessibility, a fast food outlet or retailer simultaneously evaluates several factors such as road patterns, road conditions and barriers (Jaravaza \& Chitando 2013:305). Considering that in South Africa many consumers rely heavily on public transport, accessibility to franchise fast food outlets is pivotal. Indeed, if the accessibility of the shopping centre does not allow for ease of access to retail and fast food outlets, this will decrease the chance of consumers patronising the retail location and negatively influence growth (Strydom 2014:3). Building on past empirical findings (North \& Kotze 2004:32) and by conceptualising accessibility broadly in terms of parking availability, level of security, access to the main transport route as well as ease of access to the retail mall itself, in the first instance it is predicted that:

Hypothesis 1: There is a positive relationship between accessibility and revenue growth of franchised fast food outlets

Competitive intensity: Competitive intensity is conceptualised as the level of direct competition that the focal firm faces within its immediate business domain (Doherty 2009:529; Emerson 2010:191). Competitive intensity can increase competitive advantage and influence consumer purchasing behaviour over time because competition erodes customers' perceptions of differential advantage along unsustainable dimensions (Doherty 2009:533). In South Africa, the increased competition from international brands such as Domino's, Pizza Hut and Burger King entering the local market place have put pressure on local franchise fast food outlets in recent years (FASA 2014:14). Emerson (2010:193) finds that increased competition from international competitors and saturation of local brands tend to drive both prices and profitability down as competing brands look to get a bigger piece of the market share. Consequently, saturation and cannibalisation of existing stores encroaching on existing trade areas can lead to reduction of the probability of growth (Emerson 2010:195). Thus:

Hypothesis 2: There is a negative relationship between perceived competitive intensity increase and revenue growth of franchise fast food outlets
Convenience: Convenience is a multidimensional construct and research shows that convenience is significantly related to customer satisfaction and behavioural intentions, consumer switching behaviour and customer perceptions and retention (Strydom 2014:4). Convenience has also been found to act as a positive moderator of satisfaction's effects on repurchase visits and spending. Location and convenience are well established key success factors within the retail environment, which interact with other factors to influence consumers' store choice and include price, selection of products and service levels of competitors (Jaravaza \& Chitando 2013). Convenience and ease of transporting goods to the household are important considerations which ultimately drive down the cost for the consumer of travelling to a major retail mall as opposed to selecting a closer local mall (Strydom 2014:4; Terblanche \& Boshoff 2010). Convenience plays a vital role as many consumers visit a preselected retail shopping centre that is located within walking distance of their home and or along a main transport route (Jaravaza \& Chitando 2013). Consequently it is expected that:

Hypothesis 3: There is a positive relationship between convenience and revenue growth of franchised fast food outlets

Central facilities: The optimal retail location mix of both tenants and offerings is crucial to franchise success in order to attract the maximum number of consumers within a given trade area. As each retail location is unique with its own demands, store outlets must take cognisance of their trade area and ensure their offerings are in line with the market requirements (Jaravaza \& Chitando 2013:307). Central facilities of a retail establishment are comprised of many different offerings as noted by Wong et al. (2001:27) and include: banking facilities, major retailers and supermarkets, various specialised retail shops and entertainment facilities, which must not only fit with the surrounding trade area but also act as a pull factor for consumers who patronise the retail mall. Research finds that clusters of retail stores within a shopping centre generate increased consumer traffic (Jaravaza \& Chitando 2013:307). The location of fast food outlets within retail establishments is often primarily located within a food court or strip mall area where many competitive offerings are available (Shaw 2009). This strategy coincides with the central placement theory of location (Grosh \& Craig 1983), which supports the generalised assumption that consumers will patronise the closest available store within the retail environment; thus, the stores located closer to the entrance of the mall or in an emerging market closer to a main transport route should perform at higher growth rates (Tayman \& Pol 2011:46). Building on this empirical evidence it is predicted that:

Hypothesis 4: There is a positive relationship between the central facilities of a retail location and revenue growth of franchised fast food outlets

\section{Franchise branding factors}

Building strong brand equity is vital for franchising, based on the relationship between that of franchisor and franchisee where it is essential to co-promote brand equity 
(Nyadzayo, Matanda \& Ewing 2011:1105) and customer satisfaction (Terblanche \& Boshoff 2010:3). Brand awareness, brand image and brand attributes are important for the franchising industry as consumers differentiate across the spectrum of competing brands, resulting in decisions that ultimately relate to profits, sales growth and survival (Gillis \& Combs 2009:553).

Brand awareness: Brand knowledge comprises two elements which form part of the memory node that consumers hold when identifying a particular brand; these are brand awareness and brand image. The conceptualisation of brand knowledge through memory recall is important, considering that brand awareness comprises brand recognition and brand recall performance (Keller 1993). Brand recognition relates to the consumers' ability to ratify a prior experience with a product utilising the brand as a clue, whereas brand recall refers to a consumer's ability to recall the brand when given a product category. Brand awareness within the fast food industry has been found to have a positive influence and significantly strengthen the brand relationships that customers display towards their preferred fast food offering (Mackay et al. 2013).

Brand image: Brand image, according to Keller (1993), is the perception of the brand as reflected by associations, which are embedded in the consumer's memory. Brand associations are the additional information nodes that are connected to the brand node in the consumer's memory and embrace the meaning of the brand. In the fast food industry, brand image typically refers to the sum of emotional perceptions, ideas or symbolic attitudes that customers associate with restaurants (Mackay et al. 2013:68).

Brand attributes: Product-related attributes refer to the physical composition of the product such as the ingredients required to produce the product, while non-product-related attributes refer to price information, packaging and the product's visual appearance (Keller 1993). Product-related attributes such as taste, texture and quality are important in understanding how consumers differentiate between brands. Differences between the brands are communicated overtly by making comparisons with competing brands' attributes or tacitly without stating their obvious competitive advantage. A brand's success is weighted heavily on both direct and indirect factors of the brand attributes and its positioning in the market, which is key to ensure the continuous consumption of the product (Odin, Odin \& Valette-Florence 2001:75).

Price and promotion: Related to brands, price is an important attribute as consumers have beliefs regarding the association between price and value of a brand. Therefore, price promotions on higher quality brands have shown to take market share away from similarly priced quality tier brands and lower tier brands. However, lower tier brands with price promotion will not take any market share from the higher tier brands but rather cannibalise similarly priced brands (Roberts-Lombard 2009:236).
In summary, brand awareness, brand image, brand attributes and pricing and promotion are important considerations for fast food franchise outlets as consumers rely on these factors to differentiate across the spectrum of competing brands, which ultimately influences sales growth (Gillis \& Combs 2009:556; Terblanche \& Boshoff 2010). Moreover, in acknowledging the importance of how the consumer interacts with a product or service of a certain brand through brand awareness, firms recognise the need to consistently deliver a superior quality product in order to increase customer loyalty, which will result in greater revenue streams and the cost of acquiring new customers will be reduced (RobertsLombard 2009:236). Consequently, it is hypothesised that:

Hypothesis 5: There is a positive relationship between (a) brand awareness, (b) brand image, (c) brand attributes and (d) price and promotion and revenue growth of franchised fast food outlets.

\section{Research design and methodology}

\section{Sampling and data collection}

To statistically test the hypotheses, the focus of the study was on the franchise fast food industry in South Africa and the sample was drawn from customers at two leading chains from the Famous Brands Group, across the greater Gauteng region. Two leading fast food brands who are both prominent market leaders were selected and thus the sampling frame represents customers purchasing categories of franchised fast food, in terms of hamburger and pizza offerings. The respondents, as well as the participating fast food outlets, will remain anonymous.

A convenience sampling technique was used at the store or outlet level of analysis, with a random sample selection of the sub-population taking place at several franchise outlets. All the targeted franchised fast food outlets were located in Gauteng and operated in either regional retail centres, small regional malls or community centre malls. The site locations were spread across the greater Johannesburg area and included the townships of Soweto and Alexandra, which allowed for sufficient segmentation of consumers from LSM 4 to LSM 10 to be surveyed.

Demographic characteristics of respondents reveal that the majority of respondents (58\%) were in the 18-25 age category, while $65 \%$ were female. Close to half ( $48 \%$ ) of the respondents indicated that they purchased fast foods twice a week and $36 \%$ revealed that the most common form of transport used to visit the fast food outlet was public transportation.

\section{Instruments}

Based on the literature review, suitable measures for the purpose of this study were identified where theoretical and empirical support for each construct was evident. Primary data were collected for the various items representing the independent variables (IV) and objective secondary data for the items representing the dependent variable (DV), all of 
which were based on the conceptualisation of the constructs as discussed in the literature review. Multiple items were used to measure each of the constructs representing the IVs and the DV and these were operationalised as follows.

Franchise site location factors: The following factors were hypothesised to influence consumers' choice of franchise fast food outlets: accessibility, intensity of competition, convenience and central facilities available. Past research (Frasquet et al. 2001; North \& Kotze 2004; Wong et al. 2001) has used elements of the SCATTR instrument to assess retail attractiveness factors and these were adapted in terms of the fast food franchising for use in our study: (1) Accessibility was measured with items such as 'the shopping centre is easy to access', 'the shopping centre has good parking' and 'the shopping centre has good security'; (2) Competitive intensity was measured with items such as 'the shopping centre has many fast food outlets to choose from' and 'there are many fast food outlets located within one kilometre'; (3) Convenience of the retail location was measured with items such as the shopping centre is located within one kilometre of work or home', 'I choose the closest shop when I enter the shopping centre' and 'the shopping centre is well established'; (4) Central facilities within the retail location was measured with items such as 'the shopping centre has a bank that I use' and 'the shopping centre has many shops that I use'.

Franchise brand factors: A combination of brand awareness, brand image and brand attributes scales that have been used in past studies were adapted in context of the fast food franchising for use in our study (Mackay et al. 2013; Terblanche \& Boshoff 2010). (1) Brand awareness was operationalised with variables such as 'my restaurant brand is located within one kilometre of my workplace', 'my restaurant brand is easy to locate within the shopping centre' and 'my restaurant brand has good visible signage'. (2) Brand image was based on variables such as 'the brand logo allows me to find my restaurant easily' and 'I know what to expect when I see the logo'. (3) Brand attributes was based on variables such as 'the food is served hot' and 'the quality of the food is fresh'. (4) Price and promotion was operationalised with variables such as 'the food is good value for money' and 'prices are competitive'. (The price point and promotional offering that was available at the store level was based on a national level price and promotion basis. Additionally, all national promotions were run within the stores for the same period of time.)

Revenue growth: Although there is no consensus on the appropriate measure of firm performance, researchers have pointed to growth as the crucial indicator of performance (Steffens, Davidsson \& Fitzsimmons 2009). It has also been argued that growth is a more accurate and easily accessible performance indicator than accounting measures and hence superior to indicators of financial performance (Steffens et al. 2009). Five-point scales were used for the revenue growth measures, anchored by ' $1=$ much more than' and ' $5=$ much less than'. The sales revenue or turnover revenue was collected from audited sales reports submitted from the selected store outlets to Famous Brands on a monthly basis. The period used for the sales information analysis included a year-on-year comparison from 01 March 2014 to 30 November 2014 and 01 March 2015 to 30 November 2015. This allowed for an average trading period of 10 months to be assessed, including both peak and off-peak trading months. The yearon-year growth percentage was calculated through the difference between average revenue for 2014, less the average revenue for 2013. Absolute growth was simply computed as the size at one year minus the size of the previous year.

\section{Procedure and data quality checks}

All items for the IVs were measured along a five-point Likerttype scale, ranging from ' $1=$ mostly agree' to ' $5=$ mostly disagree', where respondents were required to indicate the extent of their agreement with each statement. In some instances items were reverse coded in the scale analyses and the wording was adjusted to reflect a franchise fast food context. Since the study used a self-report questionnaire to capture the individual-level measures at one point in time, common method bias may affect empirical results and conclusions. A number of procedural steps were taken to minimise the risk. In order to reduce socially desirable responses and item ambiguity, the questionnaire featured specific, clear, concise items, with a 'counter-balanced' question order and the respondents could choose to remain completely anonymous (Podsakoff et al. 2003:888).

Based on the multi-item scales used, content validity from the customer's point of view was tested in order to ensure that the instrument demonstrated sufficient face validity. A preliminary analysis via a pilot test was undertaken $(n=14)$ to ensure that the respondents had no difficulties in answering the questions and there was no problem in recording the data. Finally, the instrument was checked for internal reliability and consistency. Item statistics were calculated for each factor with the Cronbach's alpha values reported in Table 1, all of which are deemed satisfactory (Cooper \& Emory 1995:265).

\section{Results}

\section{Descriptive statistics and correlations}

In addition to the reliabilities already mentioned in the measures section, Table 1 shows the descriptive and correlational statistics. The overall mean scores showed high levels of agreement with each of the variables, where the mean is the midpoint average on the 1-5 Likert scale. Most scores were closely distributed along the ' $1=$ mostly agree' part of the scale and ranged from 1.254 for central facilities to 1.955 for revenue growth. To understand the nature of the relationship between the variables, a correlation analysis was conducted. Pearson product-moment correlation coefficients were calculated for each of the scales and are reported as aggregate scores with levels of significance denoted in Table 1. The correlation matrix shows several significant correlations between the variables that were significantly and positively correlated to each other: accessibility and 
TABLE 1: Reliabilities, descriptives and correlations.

\begin{tabular}{|c|c|c|c|c|c|c|c|c|c|c|c|c|}
\hline Variables & $\begin{array}{c}\text { Cronbach's } \\
\text { alpha }\end{array}$ & Mean & $\begin{array}{l}\text { Standard } \\
\text { deviation }\end{array}$ & Accessibility & Competition & Convenience & $\begin{array}{l}\text { Central } \\
\text { facilities }\end{array}$ & $\begin{array}{c}\text { Brand } \\
\text { awareness }\end{array}$ & $\begin{array}{l}\text { Brand } \\
\text { image }\end{array}$ & $\begin{array}{l}\text { Brand } \\
\text { attributes }\end{array}$ & $\begin{array}{l}\text { Price and } \\
\text { promotion }\end{array}$ & $\begin{array}{c}\text { Revenue } \\
\text { growth }\end{array}$ \\
\hline Accessibility & 0.724 & 1.369 & 0.568 & 1 & - & - & - & - & - & - & - & - \\
\hline Competition & 0.730 & 1.377 & 0.558 & 0.196 & 1 & - & - & - & - & - & - & - \\
\hline Convenience & 0.779 & 1.261 & 0.713 & $0.293^{* *}$ & $0.385^{* *}$ & 1 & - & - & - & - & - & - \\
\hline Central facilities & 0.720 & 1.254 & 0.675 & $0.482^{* *}$ & $0.347^{* *}$ & $0.258^{*}$ & 1 & - & - & - & - & - \\
\hline Brand awareness & 0.737 & 1.973 & 0.727 & $0.335^{* *}$ & $0.270 * *$ & $0.641 * *$ & $0.167^{* *}$ & 1 & - & - & - & - \\
\hline Brand image & 0.890 & 1.848 & 0.771 & $0.383^{* *}$ & $0.261^{*}$ & $0.250^{*}$ & $0.339 * *$ & $0.462^{* *}$ & 1 & - & - & - \\
\hline Brand attributes & 0.903 & 1.471 & 0.536 & $0.290 * *$ & $0.250^{*}$ & $0.221^{*}$ & $0.269 *$ & $0.408 * *$ & $0.676^{* *}$ & 1 & - & - \\
\hline Price and promotion & 0.704 & 1.486 & 0.558 & $0.370 * *$ & $0.336^{*}$ & $0.360 * *$ & $0.390 *$ & $0.346^{*}$ & $0.431^{* *}$ & $0.448 * *$ & 1 & - \\
\hline Revenue growth & 0.717 & 1.955 & 0.976 & 0.152 & $-0.403^{*}$ & 0.223 & 0.040 & -0.220 & 0.041 & 0.022 & $0.259 *$ & 1 \\
\hline
\end{tabular}

$*, p<0.05 ; * *, p<0.01$, Sig. (2-tailed).

TABLE 2a: Stepwise linear regression results: Variables entered or removed ${ }^{\text {. }}$

\begin{tabular}{llcl}
\hline Model & Variables entered & Variables removed & \multicolumn{1}{c}{ Method } \\
\hline 1 & Central facilities & - & $\begin{array}{l}\text { Stepwise (Criteria: Probability-of- } \\
\text { F-to-enter } \leq 0.050, \text { Probability- } \\
\text { of-F-to-remove } \geq 0.100) .\end{array}$ \\
& & & $\begin{array}{l}\text { Stepwise (Criteria: Probability-of- } \\
\text { F-to-enter } \leq 0.050, \text { Probability- } \\
\text { of-F-to-remove } \geq 0.100) .\end{array}$
\end{tabular}

a, Dependent variable: Revenue growth.

TABLE 2b: Stepwise linear regression results: Variables entered or removed ${ }^{a}$ model summary.

\begin{tabular}{lcccc}
\hline Model & $\boldsymbol{R}$ & $\boldsymbol{R}^{\mathbf{2}}$ & $\begin{array}{c}\text { Adjusted } \\
\boldsymbol{R}^{\mathbf{2}}\end{array}$ & Standard error of the estimate \\
\hline 1 & $0.340^{\mathrm{b}}$ & 0.116 & 0.104 & 0.04969 \\
2 & $0.404^{\mathrm{c}}$ & 0.163 & 0.140 & 0.04868 \\
\hline
\end{tabular}

a, Dependent variable: Revenue growth.

b, Predictors: (Constant), Central facilities.

c, Predictors: (Constant), Central facilities, Convenience.

convenience $(r=0.293 ; p<0.01)$ and central facilities $(r=$ $0.482 ; p<0.01)$. Few significant correlations were detected between the variables and revenue growth, for instance competition $(r=-0.403 ; p<0.05)$.

\section{Hypothesis testing}

Regression analysis was employed to test the hypotheses, which entailed using stepwise linear regression where initially the variables contributing the most to explaining any variance in the DV were entered, with subsequent variables included based on their incremental contribution over the first variable and based on the criterion that they were statistically significant. Based on this procedure the results show that the only factors that had a significant impact on the DV revenue growth were convenience and central facilities; see Table $2 \mathrm{a}-\mathrm{b}$. The regression results show model 1 with a $R^{2}=0.116$ and model 2 with a $R^{2}=0.163$, which means that these two predictors combined explain $16.3 \%$ of variance in the DV. The analysis of variance (ANOVA) section (not shown) shows an $F$-value of 7.106 which is statistically significant $(p<0.01)$. In terms of standardised coefficients the beta weights indicate negative $t$-values of which central facilities is significant at the 0.05 level. An examination of the collinearity diagnostics (not shown) reveals relatively average variance proportions for the variables. These diagnostics when read in conjunction with collinearity statistics show variable inflation factor
(VIF) values of 1.084. These figures are deemed acceptable, indicating no major incidence of multicollinearity. When the values are 10.0 or more the regression coefficients can fluctuate widely from sample to sample, making it risky to interpret the coefficients as indicators of the predictors (Cooper \& Emory 1995:598).

These regression results mean that only hypothesis 3 and hypothesis 4 are supported, where significant findings provide evidence of a positive relationship between convenience $(\mathrm{H} 3)$ and central facilities of a retail location $(\mathrm{H} 4)$ and revenue growth of franchise fast food outlets. Moreover, based on the limited amount of variance (16.3\%) explained by the two IVs on the DV, the predictive and explanatory power of this model is limited and a fair amount of work needs to be conducted to further understand the influence of site location factors and brand factors on revenue growth of fast food franchises. Based on the results hypothesis 1, hypothesis 2 and hypothesis 5 cannot be supported.

\section{Ethical consideration}

The instrument was solicited from customers at 12 franchise outlets. Permission was obtained from the franchisee vis-avia the franchisors to voluntary undertake the survey and ethical clearance was obtained from the participating franchisors. Field workers randomly approached consumers directly after they had placed their order at the service counter. As noted by (Gilbert \& Veloutsou 2006:298), such a procedure ensures that a true reflection of customer feedback is captured. In order to correct for any sample bias it was ensured that the consumers selected all fell within the same time frame (lunch time trade for one full week between 12:00 and 14:00). Once 140 complete and eligible questionnaires were obtained, this served as the final sample for the study.

\section{Discussion}

The overall findings emanating as empirical evidence from the study find that only convenience and central facilities of a retail location were found to positively and significantly influence the growth of a franchisee. These results are in line with previous findings: Strydom's (2014) study showed that convenience, particularly in a regional mall centre, was important as consumers view restaurant 
franchise outlets as conveniently located within a larger shopping area which can be seen as a 'one-stop shop' destination offering a mix of products and services. Similarly, Jaravaza and Chitando (2013) find that convenience and central facilities play a major role when consumers choose a retail shopping centre. These findings confirm that site selection is primarily based on the proximity of complimentary outlets and store factors such as service quality and time and effort costs. Moreover, in terms of central facilities, past research finds that anchor tenants, specifically leading national supermarkets and major banks, play a major role in franchise site selection. The increased demand for cash withdrawals shows that consumers require a banking facility, which has been linked to increased store outlet turnover (Shaw 2009).

Although past research (Terblanche \& Boshoff 2010) shows that accessibility is an important pull factor when consumers select a fast food offering, the present study results did not find any significant influence for this variable on revenue growth. Similarly, increased levels of competition did not seem to influence revenue growth. A plausible explanation for these results may be that while increased competition leads to revenue growth, it may also have a negative influence as customer density also increases with increased competition, as do wait expectations which then lead to lower levels of customer service and subsequently revenue loss (Emerson 2010).

Surprisingly, the results did not find any of the brand factors had a significant influence on revenue growth. Considering that brand awareness is dependent on the strength of the franchise brand and signifies the quality of product as promised by the brand and communicated through advertising and brand building capabilities, it was anticipated that these brand factors would directly influence revenue growth (Dick, Jain \& Richardson 1996). Perhaps in the present study the influence of brand was perceived as more indirect when customers already have an understanding of what the brand stands for and are aware of the franchise brand presence in a shopping centre. A study in South Africa corroborates this explanation to some extent, insofar as it found that fast food consumers from medium and low socioeconomic groups were directly and highly influenced through media advertising as compared to the high socioeconomic group, where the majority of consumers suggested that indirect brand building (mostly television advertising) was the most influential form of creating brand awareness (Van Zyl et al. 2010:129).

\section{Implications and recommendations}

By placing franchise site location factors and branding in the foreground and by relying on a sample of customers frequenting leading franchise fast food outlets, the findings of this study have important implications for both scholars and practitioners:

- Scholarly implications of this study relate to the empirically derived factors, which add to the growing knowledge base and provide greater and clearer understanding of how these factors may be related to growth performance.

- Practitioner implications relate to an enhanced understanding for the franchisor and franchisee of the importance of site selection and the importance of brand awareness across segmented markets so as to provide direction and guidance for the marketing of fast food brands.

- The rise in the black middle class segment in South Africa and increasing consumption of fast foods offer huge opportunities for franchise fast food outlets that wish to differentiate their service offerings. By focusing on site location and brand factors, franchises will be able to improve their branded offerings (Mackay et al. 2013).

- The findings of this study also offer franchised fast food outlets benchmarks for determining which factors have the greatest influence on revenue growth.

- Franchisees considering expanding their current portfolios or new franchisees may benefit from the empirically derived findings in terms of the site location factors found to significantly influence revenue growth.

- Potential franchisees need to focus their strategic attention on site selection factors such as convenience and central facilities before making a decision to enter into franchising. Potential franchisors also need to consider the importance of these site location factors when conducting feasibility studies to open new stores.

\section{Limitations and future research}

The study is limited in its concentration on a single industry franchised fast foods. Every industry, however, has a different set of factors which might influence their revenue streams. Thus, the findings of this study may not generalise across franchising or industries. Future studies could expand the sample frame across multiple franchise sectors to improve generalizability. Moreover, the study's measures of franchise performance focused solely on revenue growth as a single criterion. Future studies could consider additional performance measures as well as non-financial measures in evaluating franchise success, to counteract such deficiencies.

\section{Conclusion}

The purpose of this study was to empirically examine the influence of site location and brand factors on revenue growth across franchised fast food brands. The study complements established literature by adding franchisingspecific insights from the consumers' viewpoint. Moreover, considering that knowledge on franchising in emerging markets is fragmented, with existing research focusing almost exclusively on North American contexts, the study findings are valuable in the South African context. The study has implications for practitioners who need to take into account which factors influence revenue growth, since targeted interventions may be required to implement sustainable strategies by franchisors. Furthermore, it is anticipated that this study may serve as a catalyst for this growing and important activity in South Africa and other similar emerging markets. 


\section{Acknowledgements}

\section{Competing interests}

The authors declare that they have no financial or personal relationship(s) that may have inappropriately influenced them in writing this article.

\section{Authors' contributions}

C.W. carried out the empirical work and contextualised the study. B.U. conceptualised the study and wrote the article.

\section{References}

Combs, J.G., Michael, S.C. \& Castrogiovanni, G.J., 2004, 'Franchising: A review and avenues to greater theoretical diversity', Journal of Management 30(6), 907-931. https://doi.org/10.1016/j.jm.2004.06.006

Cooper, R.D. \& Emory, C.W., 1995, Business research methods, 5th edn., Irwin Inc., Chicago, IL.

Dick, A., Jain, A. \& Richardson, P., 1996, 'How consumers evaluate store brands', Journal of Product \& Brand Management 5(2), 19-28. https://doi. org/10.1108/10610429610119405

Doherty, A.M., 2009, 'Market and partner selection processes in international retail franchising', Journal of Business Research 62(5), 528-534. https://doi.org/ 10.1016/j.jbusres.2008.06.011

Emerson, R.W., 2010, 'Franchise encroachment', American Business Law Journal 47(2), 191-290. https://doi.org/10.1111/j.1744-1714.2010.01094.x

Franchising Association South Africa (FASA), 2014, Guidelines and industry overview, viewed 29 June 2015, from http://www.fasa.co.za/guidelines.php

Frasquet, M., Gil, I. \& Molla, A., 2001, 'Shopping-centre selection modelling: A segmentation approach', The International Review of Retail, Distribution and Consumer Research 11(1) 23-38. https://doi.org/10.1080/09593960122279

Gilbert, G.R. \& Veloutsou, C., 2006, 'A cross-industry comparison of custome satisfaction', Journal of Services Marketing 20(5), 298-308. https://doi.org/ satisfaction', Journal of Service

Gillis, W.E. \& Combs, J.G., 2009, 'Franchisor strategy and firm performance: Making the most of strategic resource investments', Business Horizons 52(6), 553-561. https://doi.org/10.1016/j.bushor.2009.07.001

Goodchild, M.F., 1984, 'ILACS: A location-allocation model for retail site selection', Journal of Retailing 60(1), 84-96.

Grosh, A. \& Craig, C.S., 1983, 'Formulating retail location strategy in a changing environment', The Journal of Marketing 47(3), 56-68. https://doi.org/ $10.2307 / 1251197$

Hsu, L.-T.J., Jang, S.S. \& Canter, D.D., 2010, 'Factors affecting franchise decisions in the restaurant industry', Journal of Hospitality \& Tourism Research 34(4), 440-454. https://doi.org/10.1177/1096348009350647

Hua, N. \& Dalbor, M.C., 2013, 'Evidence of franchising on outperformance in the restaurant industry: A long term analysis and perspective', International Journal of Contemporary Hospitality Management 25(5), 723-739. https://doi.org/10.1108/ Contemporary Hospitality
IJCHM-Aug-2012-0138

Hua, N. \& Templeton, A., 2010, 'Forces driving the growth of the restaurant industry in the USA', International Journal of Contemporary Hospitality Management 22(1), 56-68. https://doi.org/10.1108/09596111011013471

IFA, 2015, The International Franchise Association, educational foundation, USA, viewed 21 April 2015, from http://www.ifa.com/educationalfoundation.php

Jaravaza, D.C. \& Chitando, P., 2013, 'The role of store location in influencing customers' store choice', Journal of Emerging Trends in Economics and Management Sciences 4(3), 302-307.

Kacker, M., Dant, R.P., Emerson, J. \& Coughlan, A.T., 2013, 'How firm strategies impact size of partner-based retail networks: Evidence from franchising', Journal of Small Business Management 4(2), 21-37.
Keller, K.L., 1993, 'Conceptualizing, measuring, and managing customer-based brand equity', The Journal of Marketing 57(1), 1-22. https://doi.org/10.2307/1252054

Mackay, N., Spies, H., Williams, C., Jansen Van Rensburg, L.J. \& Petzer, D.J., 2013, 'The influence of service brand equity on the strength of brand relationships in the fast food industry', Southern African Business Review 17(2), 67-92.

Michael, S.C. \& Combs, J.G., 2008, 'Entrepreneurial failure: The case of franchises', Journal of Small Business Management 46(1), 73-90. https://doi.org/10.1111 /j.1540-627X.2007.00232.x

Nijmeijer, K.J., Fabbricotti, I.N. \& Huijsman, R., 2013, 'Making franchising work: A framework based on a systematic review', International Journal of Management Review 16(1), 62-83. https://doi.org/10.1111/ijmr.12009

North, E.J. \& Kotze, T.K., 2004, 'Customer perceptions of the attractiveness of shopping centres in Pretoria', South Africa Journal of Business Management 8(1), 30-38.

Nyadzayo, M.W., Matanda, M.J. \& Ewing, M.T., 2011, 'Brand relationships and brand equity in franchising', Business to Business Branding 40(7), 1103-1115. https:// doi.org/10.1016/j.indmarman.2011.09.004

Odin, Y., Odin, N. \& Valette-Florence, P., 2001, 'Conceptual and operational aspects of brand loyalty: An empirical investigation', Journal of Business Research 53(2), 75-84. https://doi.org/10.1016/S0148-2963(99)00076-4

Podsakoff, P.M., Mackenzie, S.B., Jeong-Yeon, L. \& Podsakoff, N.P., 2003, 'Common method biases in behavioural research: A critical review of the literature and recommended remedies', Journal of Applied Psychology 88(5), 879-903. https:// doi.org/10.1037/0021-9010.88.5.879

Roberts-Lombard, M., 2009, 'Customer retention strategies of fast-food outlets in South Africa: A focus on Kentucky Fried Chicken (KFC), 'Nando's and Steers', Journal of African Business 10(2), 235-249. https://doi.org/10.1080/ Journal of African

Shaw, M., 2009, Determinants of successful outlets in the South African quick services restaurant industry, Unpublished Masters Dissertation, University of Pretoria, Pretoria.

So, K.K.F., King, C., Sparks, B.A. \& Wang, Y., 2013, 'The influence of customer brand identification on hotel brand evaluation and loyalty development', International Journal of Hospitality Management 34(1), 31-41. https://doi.org/10.1016/j. ijhm.2013.02.002

South African Audience Research Foundation (SAARF), 2012, 'SAARF reveals the truth behind Soweto's LSM 10's', The Media, 25 May, pp. 28-29.

Stats SA, 2014, Statistics South Africa. Food and beverage, viewed 18 September 2015, from http://www.statssa.co.za/listings2014/foodandbeverage/co.za

Steffens, P., Davidsson, P. \& Fitzsimmons, J., 2009, 'Performance configurations over time: Implications for growth- and profit-oriented strategies', Entrepreneurship: Theory \& Practice 33(1), 125-148. https://doi.org/10.1111/j.1540-6520.2008. 00283.x

Steyn, N.P., Labadarios, D. \& Nel, J.H., 2011, 'Factors which influence the consumption of street foods and fast foods in South Africa a national survey', Nutrition Journa 10(1), 104-124. https://doi.org/10.1186/1475-2891-10-104

Strydom, J., 2014, 'The relationship between key demographic profile descriptors and the propensity for in shopping and out shopping by Sowetan residents', Southern the propensity for in shopping and out
African Business Review 18(1), 1-21.

Tayman, J. \& Pol, L., 2011, 'Retail site selection and geographic information systems', Journal of Applied Business Research 11(2), 46-54. https://doi.org/10.19030/jabr. v11i2.5874

Terblanche, N.S. \& Boshoff, C., 2010, 'Quality, value, satisfaction and loyalty among race groups: A study of customers in the South African fast food industry', South Africa Journal of Business Management 41(1), 1-9.

Urban, B. \& Kongo, M., 2015, 'The relevance of human capital on firm performance: A focus on the retail industry in Kinshasa, DRC', Acta Commercii 15(1), 1-9. https:// doi.org/10.4102/ac.v15i1.261

Van Wyk, G.J. \& De Jager, J.W., 2009, 'Franchisees' level of satisfaction with the franchise relationship', Acta Commercii 9(1), 119-128.

Van Zyl, M., Steyn, N.P. \& Marais, M.L., 2010, 'Characteristics and factors influencing fast food intake of young adult consumers in Johannesburg, South Africa: Original research', South Africa Journal of Clinical Nutrition 23(3), 124-130. https://doi.or $\mathrm{g} / 10.1080 / 16070658.2010 .11734326$

Wong, G.K.M., Lu, Y. \& Yuan, L.L., 2001, 'SCATTR: An instrument for measuring shopping centre attractiveness', International Journal of Retail \& Distribution Management 29(2), 76-86. https://doi.org/10.1108/09590550110381535 